\title{
MANAGEMENT OF FACILITIES AT PUBLIC UNIVERSITIES IN AFRICA: CURRENT CHALLENGES AND THE WAY FORWARD
}

\author{
Samuel H.P. Chikafalimani \\ Department of Construction Management and Quantity Surveying \\ Durban University of Technology, Durban, South Africa \\ e-mail:samuelc@dut.ac.za
}

\section{Nathan Kibwami}

Department of Construction Economics and Management

Makerere University, Kampala, Uganda

e-mail:knathan@cedat.mak.ac.ug

\section{Sibusiso Moyo}

Research, Innovation and Engagement

Durban University of Technology, Durban, South Africa

e-mail:dvcrie@dut.ac.za

\begin{abstract}
This paper provides an overview of the challenges of management of facilities at public universities in Africa. Results reveal that: poor condition and the overcrowding of facilities, limited skills and capabilities of facility management departments, and lack of financial resources are the main challenges which the management of facilities at public universities in Africa faces. In worse situations, these problems have adversely affected the quality of the learning and teaching environment at the institutions and also threatened their existence. Prioritization of funding for the provision and improvement of quality facilities at public universities by governments, employment of well qualified and trained staff in the facility management departments at the public universities, and creation of innovative and smarter public-private partnerships aimed at the improvement of existing facilities and provision of new ones were identified as the key solutions that can be implemented to address the challenges that public universities in Africa are facing in relation to facilities. Findings will support public universities in Africa to address challenges of management of their facilities so that they can continue to achieve their intended objectives of offering high quality higher education, research and community engagement in order to accelerate socio-economic development of their countries on the continent in the future.
\end{abstract}

Key words: management of facilities, public universities, Africa.

JEL Classification: $D 46, H 82, K 11, L 85, R 00, R 14, R 20, R 21, R 22, R 23, R 28, R 29, R 30, R 31, R 39, R 51$, $R 52, R 53$

Citation: Chikafalimani, S.H.P., Kibwami, N. \& Moyo, S. (2021). Management of facilities at public universities in Africa: current challenges and the way forward. Real Estate Management and Valuation, 29(1), 21-29.

DOI: https://doi.org/10.2478/remav-2021-0003 


\section{Introduction}

History shows that most African nations strove to establish at least one national public university immediately after independence (Mosha, 1986). A public university from the African perspective is defined as an institution of higher education and research, which grants academic degrees in a variety of disciplines and is in state ownership or receives significant public funds from government (SAStudy, 2020; Wikipedia, 2020). Morsha (1986) further elaborated that the major aim for African countries to establish public universities was for the institutions to play a pioneering role in addressing problems of poverty, social disorganisation, low production, unemployment, hunger, illiteracy and diseases which are the problems of underdevelopment that appeared to be common on the African continent soon after independence. In order to achieve these objectives, quality teaching and learning facilities at public universities for the students and staff are critical. Unfortunately, challenges related to facilities at most of the public universities in Africa due to political, demographic, economic and financial problems, among other challenges, have continued to threaten the existence of the institutions by creating poor quality learning and teaching environment for students and staff (Mosha, 1986). Therefore, the purpose of this paper is to examine the current challenges of managing facilities at public universities in Africa. Thereafter, suggestions that can assist with the improvement of existing old or the provision of new facilities at the institutions are given. The proposed solutions will support the public universities in Africa to continuously deliver a high quality teaching and learning environment to their students and staff through the provision of good facilities. This will consequently enable the institutions to achieve their intended core objectives of offering higher education, teaching and learning, research and community engagement in the future. Figure 1 exhibits a Map of Africa showing its countries, while Table 1 contains the names of some of the public universities which exist in Africa.

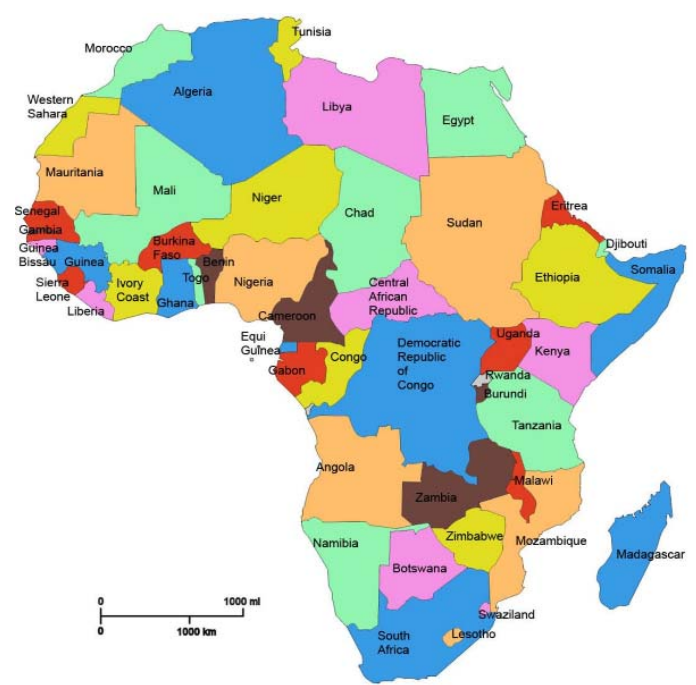

Fig. 1. Map of Africa. Source: Google.com / search at www.google.com (accessed 30.04.2020).

List of some of the public universities in Africa

\begin{tabular}{ll}
\hline 1 & Univesity of Malawi \\
\hline 2 & University of Al Alkhawayn, Morroco \\
\hline 3 & University of Nairobi, Kenya \\
\hline 4 & University of Swaziland \\
\hline 6 & University of Zambia \\
\hline 7 & University of Zibwabwe \\
\hline 8 & Lagos State University, Nigeria \\
\hline 10 & Kwame Nkrumah University of Technology, Ghana \\
\hline 11 & Cairo University, Egypt \\
\hline
\end{tabular}

Source: Wikipedia (2020). 


\section{Literature Review}

Some authors have lamented about the poor condition and overcrowding of facilities at most of the public universities in Africa. Ndirangu and Udoto (2011) conducted a study on the perceptions of quality of educational facilities at public universities in Kenya. The results of their survey revealed that the quality of the library and lecture facilities provided by Kenyan public universities could not be considered adequate. In addition, Ndirangu \& Udoto (2011) complained that the public universities were unable to support the desired educational programs effectively and facilitate the development of learning environments that support students and teachers in achieving their goals. Furthermore, they observed that facilities were the antithesis of healthy and secure facilities that can provide a stimulating and inspirational setting for users, who happen to be the critical judges of the quality of facilities. Related findings on the poor condition of facilities at public universities in Africa were also reported by CHE Lesotho (2012); Mendonca (2014); Adamu and Shakantu (2016); Abdullahi et al. (2017); Wanie et al. (2017); and Oyedeji (2018). Apart from the poor condition of the facilities, the Africa-America Institute (2015) equally lamented that most facilities at public universities in Africa are neglected and overcrowded. Of significance, the Institute emphasized that the rapid increase in the student enrolment numbers at most public universities in Africa was the major contributing factor to the deterioration of the quality of several aspects at the institutions, which include poor condition of the facilities due to enormous pressure exerted on limited financial resources and tight budgets caused by the ever-increasing student populations being registered at the institutions.

Facilities are defined in short by the South African Facilities Management Association (SAFMA) as all physical entities where products or services are created, stored and distributed, whereas facilities management is defined as the management of specific entities to enable the business to carry out its core functions (SAPET, 2002). However, Moeng (1998) offered a much more detailed definition of facilities management which states that: "facilities management is the process whereby principles of business administration, architectural, behavioral and engineering sciences are integrated and coordinated within a learning and changing environment typified by the work of the organization. This process is composed of physical and human assets which are constantly being managed to adapt to change, leading to the economic maintenance, improvements, adaption, planning, design and management of occupied buildings. This is done through the creation and sustenance of a particular status quo in order that programmatic objectives can be realized and ultimately result in organizational effectiveness." As noted, these definitions reveal that facilities management provides a supporting management function to the core business of an organization and concentrates on the area of interface between the physical workplace and people (Carder, 1997; Wisittigars \& Siengthai, 2019).

International Facility Management Association (IFMA) (cited in SAPET, 2002) provided a guideline for job descriptions of facilities managers and categorized them into nine functional areas which are given in Table 2 below. They range from long range facility planning to telecommunications integration. In addition, it is also important to note that the facilities management department in an organization does not operate in isolation. Instead, it always interacts with both the core business of the organization and the external environment. Figure 2 below exhibits the model of facilities management systems adapted from Barret (1995) (cited in SAPET, 2002) and illustrates the range of continuous interactions which are involved in facilities management. Worth noting in Figure 2 is the difference between operational facilities management and strategic facilities management which the facilities management department balances in the course of delivering its responsibilities.

Categories of facilities management job descriptions

Table 2

\begin{tabular}{ll}
\hline 1 & Long-term facility planning \\
\hline 2 & Annual facility planning (tactical planning) \\
\hline 3 & Facility financial forecasting and budgeting \\
\hline 4 & Real estate acquisition and disposal \\
\hline 5 & Interior space planning, work specifications, and installation and space management \\
\hline 6 & Architectural and engineering planning and design \\
\hline 8 & New construction and renovation work \\
\hline 9 & Maintenance and operation management of the physical plant \\
\hline
\end{tabular}

Source: IFMA (cited in SAPET, 2002). 


\section{S sciendo}

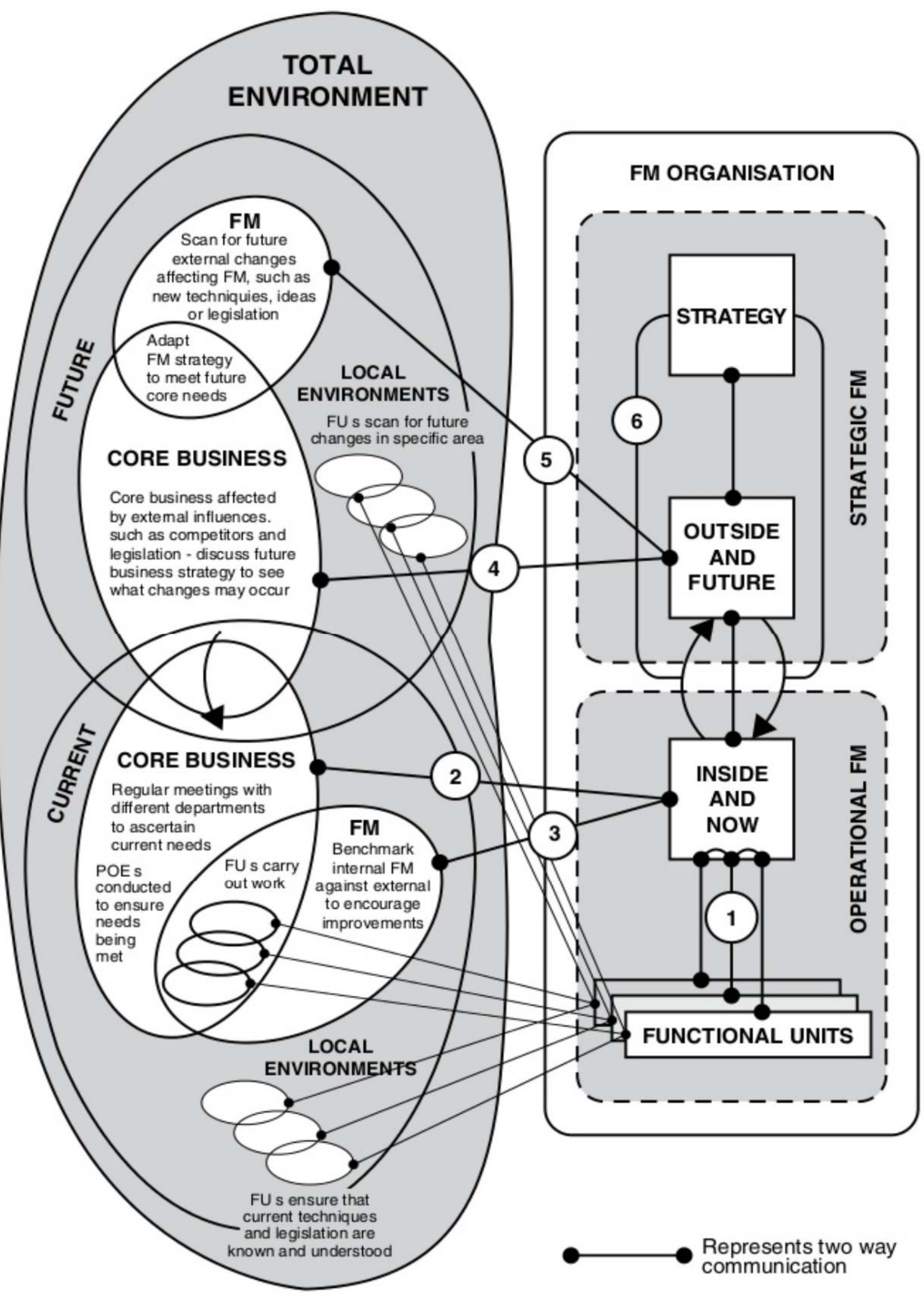

Key: $\mathrm{FU}=$ Function units. $\mathrm{FM}=$ Facilities management

Fig. 2. Model of Facilities Management Systems (Barret, 1995) (cited in SAPET, 2002). 
Operational facility management involves: interactions within the facilities department itself between the facilities manager and the different functional units; whereby the facility manager interacts on a regular basis with the core business to identify current facility requirements; and finally the facility manager benchmarks existing internal facility services against other facility management organizations, so that probable areas for improvement can again be identified. On the other hand, Barret (1995) (cited in SAPET, 2002) indicated that, in strategic facility management: the facilities manager interacts with the core business to ascertain what future changes may occur in a business as a response to external influence, such as a competitor's plans; the facility manager will also scan for possible developments within the facility management area; and strategy is the policy framework which provides the context for decision making within the facility management department. At this point interaction occurs between strategic and operational facility management, the aim being to synergistically balance current operations with the needs of the future.

Nielsen et al. (2012) and Støre-Valen \& Buser (2019) noted that the facilities management profession today must accommodate change by taking sustainability concerns seriously. They indicate that sustainable facilities management today: must take into account the environmental performance of buildings and incorporate environmentally friendly and safe building materials and components, such as low energy windows, low flush toilets, low energy bulbs, among others, during the design and construction of buildings. At the same time, existing buildings which have not been designed and / or built with such components (for example, old buildings) need to be maintained to preserve their use or they can be adapted or converted to be in line with current environmental trends. Cortese (2003) argues that, by accepting the leadership role in society as leaders of knowledge, research and innovation over the past decades, universities have committed themselves to making significant contributions to society's sustainable development aspirations. Therefore, their adoption of sustainable development ethos will set a good example for the approach of other organizations to facility management. During this process this will lead to the attainment of sustainable development objectives by many organizations, both locally and internationally (Awuzie \& Ari, 2017). Wang et al. (2014) identified skills in facility management as a requirement to support sustainable facility management at universities.

\section{Research Method}

The mixed research method (Creswell, 2014), which involves a combination of multiple data gathering techniques including document and report analysis, observations and conversations, was used to collect data for the paper. Data to be collected for the study on the management of facilities at public universities in Africa was categorized into four main areas. Firstly, identification of some public universities in Africa. Internet research was used to search for universities that qualified as public universities in Africa. Secondly, data on the types of common facilities at public universities and their condition was collected using mainly observations, publications and conversations with users of the facilities at the institutions. Thirdly, data on the capabilities of facility management departments at the public universities was obtained, mainly from related publications and conversations held with the users of the facilities. Finally, information on the lack of financial resources was obtained from relevant documents.

\section{Results, Analysis and Discussion}

Findings of the study on the lessons learnt from the research as well as challenges facing management of facilities at public universities in Africa are critical and discussed in the subsequent section. Table 5 summarizes proposed solutions to the main challenges facing the management of facilities at public universities in Africa.

\subsection{Condition of facilities}

Through the study, it was noted that public universities in Africa own similar types of facilities at their campuses. Table 3 contains a list of common types of facilities found at the public universities which are frequently used by students and staff. As can be noted from Table 3, public universities own different types of facilities which provide the learning and teaching environment for students and staff. These facilities range from student and staff housing to specialized buildings which offer different types of services, to the institutions to enable them achieve their three main objectives, namely: providing higher education, conducting research and community engagement. Without these 
facilities, the institutions fail to provide their intended services and achieve their objectives (Abdullahi et al., 2017). However, it was sad to note that most of these facilities at the majority of the public universities in Africa were in poor condition of repair (Ndirangu \& Udoto, 2011; CHE Lesotho, 2012; Mendonca, 2014; Africa-America Institute, 2015; Adamu \& Shantu, 2016; Wanie et al., 2017). The Commission for Africa 2005 report (cited in Ndirangu \& Udoto, 2011) describes many public African universities as "in a state of crisis" without the basic physical infrastructure such as the internet connectivity, books, laboratory equipment and classrooms. The condition of repair of the facilities differed, of course, from one public university to another or from one country to another. Generally, the condition of facilities at public universities in South Africa, Namibia, Botswana, Mauritius and in North Africa in countries like Egypt, Tunisia, Algeria and Morocco is better than at public universities in other parts of Africa because these universitie have access to funds and are better off financially (Times Higher Education World University Rankings, 2020). Their governments too have been trying to allocate adequate financial resources to these public universities more so than the governments of poorer countries. However, even though the condition of facilities at public universities in South Africa was generally good, some universities have even better facilities than others due to the negative effects of the abolished apartheid system which discriminated African public universities from funding for good facilities and education. Table 4 shows a list of some of the common defects of facilities requiring maintenance observed at public universities.

Common types of facilities at public universities in Africa

Table 3

\begin{tabular}{ll}
\hline 1 & Student and staff housing \\
\hline 2 & Learning and teaching buildings (lecture venues, class and staff rooms) \\
\hline 3 & Laboratories \\
\hline 4 & Libraries \\
\hline 6 & Management and administration buildings \\
\hline 7 & Support services buildings \\
\hline 8 & Respitals and health clinics \\
\hline 9 & Entertainment and community halls \\
\hline 10 & Theatres \\
\hline 11 & Hotels and guest houses \\
\hline 12 & Conference buildings \\
\hline 13 & Warehouses \\
\hline 14 & Workshops and factories \\
\hline 15 & Chapels, religious and worship buildings \\
\hline 16 & Tuckshops \\
\hline 17 & Sports buildings, structures and play grounds \\
\hline 18 & Farm land, buildings and structures \\
\hline 19 & $\begin{array}{l}\text { External services and site infrastructure (paving, drains, bridges, campus street lights, streets, roads, } \\
\text { gardens, gates and fencing) }\end{array}$ \\
\hline 20 & $\begin{array}{l}\text { Special buildings (Water reservoirs and dams, water treatment plants, sewerage plants, recycling and } \\
\text { waste management plants, and power generation plants) }\end{array}$ \\
\hline
\end{tabular}

Source: Data collected through facilities inspections (2020).

Table 4

Common defects observed on facilities at public universities in Africa

\begin{tabular}{ll}
\hline 1 & Broken doors and windows \\
\hline 2 & Dirty / unpainted external and internal walls \\
\hline 3 & Damaged floors and coverings \\
\hline 4 & Broken fittings \\
\hline 5 & Leaking roof \\
\hline 6 & Damaged ceilings \\
\hline 7 & Cracked walls \\
\hline 8 & Broken writing boards \\
\hline 9 & Broken toilets \\
\hline 10 & Faulty electrical fittings \\
\hline
\end{tabular}


11 Dirty campus sites and gardens

12 Unmaintained site services: drains, streets, roads, etc.

Source: Data collected through facilities inspections (2020).

\subsection{Skills and capabilities of facilities management departments}

Wanie et al. (2017), who conducted a study on the condition of public university students' housing in Cameroon, observed that public universities had lower capacity and fewer skills to provide good accommodation to university students. As a solution to this problem, they proposed that the students themselves get involved in the management of their hostels to supplement limited public university manpower, skills and financial resources to improve the condition of students' hostels. Awozie \& Isa (2017) and Abdullahi et al. (2017) also identified skills-related challenges in the management of facilities at public universities in Africa.

\subsection{Financial resources}

Ndirangu \& Udoto (2011) and the Africa-America Institute (2015) observed that the main reason behind the poor conditions and overcrowding of facilities at public universities was the lack of adequate funding from African governments that supported the public universities. One of the reasons given by the African governments for this problem is the ever-increasing number of students registering at the universities (Africa-America Institute, 2015). But other education experts have suggested a lack of prioritization in terms of allocation of state funds as a main weakness of African governments, which has left the public universities neglected in terms of faciliy maintenance and provision (Ndirangu \& Udoto, 2011; and Mendonca, 2014). Kaplan, et al. (2011) recommended publicprivate partnerships as a potential mechanism which can be used in Africa in the future to raise funding for the improvement and provision of new facilities at public universities.

Table 5

Proposed solutions for challenges of facilities management at public universities in Africa

1 Prioritization of funding for the provision and improvement of quality facilities at public universities by governments in Africa

2 Employment of well qualified and trained staff in the facilities management departments at the public universities in Africa

3 Creation of innovative and smarter public-private partnerships aimed at the improvement of existing and provision of new facilities to constantly meet space requirements at public universities in Africa

Source: Research findings.

\section{Conclusion and Further Research}

This study was aimed at examining the challenges of management of facilities at public universities in Africa. Related studies and mixed research methods were used to collect data for the paper. Results of the study reveal that the management of facilities at most of the public universities in Africa indeed continues to face challenges. Firstly, most of the facilities at the majority of public universities were in poor condition and overcrowded. Secondly, it was also found that most of the public universities had limited skilled and incapable facility management departments, and thirdly, the majority of institutions lacked financial resources to adequately manage their facilities. These problems have had a detrimental effect on the quality of learning and the teaching environment at some public universities in Africa, with the institutions failing to fully achieve their intended objectives of eradicating poverty, social disorganisation, low production, unemployment, hunger, illiteracy, diseases and underdevelopment on the African continent. The prioritization of funding for quality facilities at public universities by governments in Africa, employment of well qualified and trained staff in facility departments at public universities, and the creation of innovative and smarter publicprivate partnerships aimed at improving facilities and providing new ones at public universities in Africa were identified as the key solutions to solving the challenges that public universities in Africa are facing in connection with the quality of their facilities. Findings will support public universities, their governments and other higher education partners in their efforts to improve existing facilities in Africa and provide new ones, in order to support the survival of the institutions on the continent so 
that they can continue to pursue their intended objectives of providing quality higher education, teaching and learning, research and community engagement to facilitate economic development of Africa. The survival of public universities is significant since they are more affordable and cater for the majority of students on the continent than private universities. More significantly, public universities in Africa are still required so that they can continue to address the problems of socio-economic differences which are still rampant on the continent. Finally, the study recommends more scientific surveys of the users of facilities at public universities and other stakeholders involved in the provision and management of facilities at public universities to a gain a more in-depth understanding and analysis of the challenges identified in this study. It is important in the future to conduct more research in this subject area so that ways of improving old facilities and supplying new ones at public universities in Africa can be discovered. With good facilities, public universities in Africa will be able to create high quality learning environment which will support them to easily continue the improvement of higher education, research and community engagement on the continent. The study also recommends that public universities accommodate sustainable facility management practices and approaches in the implementation of facility management so they can contribute towards global efforts of addressing environmental concerns.

\section{References}

Abdullahi, I., Yusoff, W. Z. W., \& Gwamna, E. (2017). A review of physical and non-physical facilities performance on student satisfaction in Northern Nigerian Universities. Journal of Social Sciences, 12(4), 600-608.

Adam, A., \& Shakantu, W. (2016). Condition assessment of student hostel buildings on campuses of Federal Universities in North-Central Nigeria. Journal of Construction Project Management and Innovation, 6(1), 1330-1338.

Africa-America Institute. State of Education in Africa Report (2012).

Awuzie, B., \& Isa, R. (2017). Stakeholders' Perception of Critical Success Factors for Sustainable Facilities Management Practice in Universities in Sub-Saharan Africa. Acta Structilia, 24, 106-127. https://doi.org/10.18820/24150487/as24i2.4

Barrett, P. (1995), cited in SAPET (2002). Introduction to Facilities Management. Cloete C.E. (ed). SAPET Publishers.

Carder, P. (1997). The Interface Manager's Toolkit. Facilities, 15, 84-89. https:// doi.org/10.1108/02632779710160586

Cortese, A. D. (2003). The Critical Role of Higher Education in Creating a Sustainable Future. Planning for Higher Education, 31(3), 15-22.

Council on Higher Education. Report on the State of Higher Education in Lesotho (2012).

Creswell, J. W. (2014). Research design: qualitative, quantitative, and mixed methods approaches (4th ed.). SAGE Publications.

Mendonca, M. (2014). Developing Teaching and Learning in Mozambican Higher Education: Study of the pedagogical development at Eduardo Mondlane University. Unpublished PhD (Education) treatise. Mondlane University.

Moeng, M. S. (1998). The role of facilities management in improving organisational performance. Unpublished MSc (QS) treatise. University of Pretoria.

Mosha, H. J. (1986). The role of African universities in national developments. The Journal of Higher Education, 15, 113-134. https://doi.org/10.1007/BF00138096

Ndirangu, M., \& Udoto, M. O. Mwangi, N., \& Udoto, M. O. (2011). Quality of learning facilities and learning environment: Challenges for teaching and learning in Kenya's public universities. Journal of Quality Assurance in Education, 19(3), 208-223. https://doi.org/10.1108/09684881111158036

Nielsen, S. B., Jensen, P. A., \& Jensen, J. O. (2012). The Strategic Facilities Management Organization in Housing: Implications for Sustainable Facilities Management. International Journal of Facilities Management, 3(1), 1-15.

Oyedeji, J. O. (2018). Facility management of Nigerian Universities: Case of University of Lagos, Lagos and Bells University of Technology, Ota, Nigeria. International Journal of Built Environment and Sustainability, 5(2), 134-144.

Sastudy. (2020). webpage at www.sastudy.co.za (accessed 27.02.2020).

SAPET. (2002). Introduction to Facilities Management (C. E. Cloete, Ed.). SAPET Publishers. 
Støre -Valen, M., \& Buser, M. (2019). Implementing Sustainable Facility Management. Facilities, 37(9/10), 550-570. https:// doi.org/10.1108/F-01-2018-0013

Times Higher Education World University Rankings. (2020). Webpage at www.timeshighereducation.com (accessed 30.04.2020)

Wang, M., Mohammed, A. H., Sapri, M., \& Rahman, M. S. A. (2014). Requisite facilities management competencies for sustainable development at higher education institutions. Journal of Sustainability Science and Management, 9(2), 71-89.

Wanie, C. M., Oben, E. E. E., Molombe, J. M., \& Tassah, I. T. (2017). Youth advocacy for efficient hostel manage and affordable university students' housing in Buea, Cameroon. International Journal of Housing Markets and Analysis, 10(1), 81-111. https://doi.org/10.1108/IJHMA-01-2016-0012

Wikipedia. (2020), webpage at www.wikipedia.org/wiki/public university (accessed on 27.02.2020).

Wisittigars, B., \& Siengthai, S. (2019). Crisis leadership competencies: The facility management sector in Thailand. Facilities, 37(13/14), 881-896. https://doi.org/10.1108/F-10-2017-0100 